\title{
ANALIZA ZAKRESU I SPECYFIKI ROZWIAZAŃ WYKORZYSTYWANYCH W RAMACH ADAPTACYJNEGO PODEJŚCIA DO ZARZAZDZANIA PROJEKTAMI
}

DOI: $10.33141 /$ po.2021.3.04

\author{
Mariusz Hofman, Magdalena Oronowicz
}

Przegląd Organizacji, Nr 3(974), 2021, s. 31-39

www.przegladorganizacji.pl (c) Towarzystwo Naukowe Organizacji i Kierownictwa (TNOiK)

\section{Wprowadzenie}

$\mathbf{P}$ owszechna obecnie zmienność otoczenia rynkowego stymuluje zjawisko projektyzacji (Schoper i in., 2018; Jałocha, 2019). Jego efektem jest rosnąca liczba projektów różnych typów, które są inicjowane, a następnie realizowane przez organizacje prowadzące działalność gospodarczą. W ujęciu makroekonomicznym wpływa to na wzrost udziału PKB, który jest efektem realizacji tych przedsięwzięć. Odmienny charakter inicjowanych projektów powoduje konieczność stosowania do zarządzania nimi różnych metodyk: kaskadowych, zwinnych lub hybrydowych (Friis Sommer i in., 2014). Z kolei zwiększająca się liczba projektów wymaga ich łączenia w zbiory w celu maksymalizowania efektywności zarządzania nimi. Nałożenie się tych dwóch zjawisk powoduje, że w organizacjach występować mogą projekty (programy, portfele) realizowane $\mathrm{w}$ oparciu o podejście tradycyjne oraz adaptacyjne, które mają odmienną specyfikę oraz są w inny sposób zarządzane.

Celem artykułu jest określenie zakresu stosowania podejścia adaptacyjnego do zarządzania projektami, w tym podejść zwinnych i wspomagających ich narzędzi, na poziomie organizacji, projektu oraz zespołu. Aby zrealizować tak postawiony cel pracy, poszukiwano odpowiedzi na następujące pytania badawcze:

- PB1 - Jakie korzyści osiąga organizacja, stosując adaptacyjne podejście do zarządzania projektami?

- PB2 - Jakie rozwiązania umożliwiające skalowanie rozwiązań zwinnych na poziom organizacji są najczęściej stosowane?

- PB3 - Jakie rozwiązania (metodyki) są najczęściej stosowane do zarządzania projektami zwinnymi?

- PB4 - Jakie narzędzia wykorzystywane są najczęściej przez zespoły projektowe takie projekty realizujące?

W badaniach wykorzystano ilościowe analizy danych, w tym statystykę opisową. Jej zastosowanie pozwoliło uporządkować zgromadzone dane oraz przeprowadzić ich późniejszą analizę w dłuższym horyzoncie czasowym. Dane empiryczne pozyskane zostały z publikowanych corocznie raportów branżowych, które dotyczyły specyfiki oraz zakresu stosowania adaptacyjnego podejścia do zarządzania projektami.

\section{Zagadnienia teoretyczne}

0 becnie rozróżnia się tradycyjne i adaptacyjne podejście do zarząazzania projektami. Istotą podejścia tradycyjnego jest fazowy model cyklu życia projektu oraz koncentracja na utrzymaniu $\mathrm{w}$ równowadze trzech parametrów (zakres, czas, budżet), które definiują cel projektu. $\mathrm{W}$ obrębie tego podejścia upowszechnily się kaskadowe (waterfall) metodyki zarząadzania projektami. Uwzględniają one istotę podejścia tradycyjnego oraz oddają jego specyfikę. Adaptacyjne zarządzanie projektami ma swoje korzenie w branży informatycznej (Dybå, Dingsøyr, 2008). Oparte jest na kilku kluczowych zasadach, z których najważniejsze to: transparentność, iteracyjny sposób pracy realizowany przez autonomiczne i samoorganizujące się zespoły oraz doskonalenie sposobu wykonywania pracy $\mathrm{w}$ oparciu o informację zwrotną przekazywaną podczas cyklicznych spotkań takich zespołów (Leffingwell, 2010). W ramach podejścia adaptacyjnego wypracowane zostały zwinne (agile) metodyki zarządzania projektem. Cechują się one ogólnością proponowanych założeń metodycznych oraz elastycznością zawartych w nich rozwiązań, która pozwala dopasować konkretną metodykę do potrzeb organizacji (Schwaber, Beedle, 2002). Stosowane są również metodyki łączące w sobie elementy różnych metodyk zwinnych (np. SCRUM XP Hybrid), jak również metoda KANBAN. Wybór właściwego podejścia oraz najlepszej metodyki zależy od projektu, sposobu jego realizacji oraz oczekiwanych efektów (Karrbom Gustavsson, Hallin, 2014).

Znaczenie zespołu jako czynnika determinującego sukces projektu jest kluczowe w przypadku podejścia adaptacyjnego. W przypadku tego podejścia to zespół kolektywnie podejmuje kluczowe decyzje w projekcie (Xiang $\mathrm{i}$ in., 2016). Odpowiednie działanie zespołu projektowego jest efektem właściwego podziału prac, zaangażowania poszczególnych członków zespołu oraz wzajemnego zaufania (Porter, Lilly, 1996). W zespole projektowym powinny znaleźć się osoby o pożądanych kompetencjach, odpowiednim nastawieniu do projektu oraz wyznające te same wartości (Shu-Chien i in., 2016). Daje to gwarancję odpowiedniej współpracy poszczególnych członków zespołu oraz eliminuje potencjalne konflikty w zespole 
(Henderson i in., 2016). Mimo wszystko, dla sprawnego działania zespołu kluczowe znaczenie ma jednak odpowiednia komunikacja, gwarantująca właściwy przepływ informacji w obrębie zespołu (Wu i in., 2017).

Dla organizacji, które chcą zarządzać zbiorami projektów realizowanych za pomocą podejścia adaptacyjnego, dostępne są rozwiązania pozwalające skalować (scale) praktyki z działających na poziomie projektu na poziom portfela (Leffingwell, 2007). W przypadku tych rozwiązań kluczowe jest zarządzanie portfelem projektów zwinnych (agile portfolio management). W tradycyjnym ujęciu portfel łączy pojedyncze projekty w taki sposób, aby maksymalizować uzyskaną wartość przy założonym poziomie ryzyka (Markowitz, 1959; Patanakul, Milosevic, 2009; Olsson, 2008). W podejściu tradycyjnym określanie właściwej struktury portfela jest więc kluczowym aspektem zarządzania portfelem projektów (PMI, 2008). Istotne jest również, aby odpowiednia struktura portfela pozwoliła zrealizować określone zamierzenia strategiczne (Meskendahl, 2010). Natomiast w przypadku zarządzania portfelem projektów zwinnych istotna jest transparentność portfela (jeden w organizacji), jednorodność (homogeniczność) oraz współpraca i zaangażowanie (osób z poziomu portfela, jak też projektów) (Stettina, Hörz, 2015). W przypadku portfela projektów zwinnych długookresowe zamierzenia organizacji ujmowane są $\mathrm{w}$ rejestrach portfela lub mapach drogowych produktu (Laanti $i$ in., 2013). Zatem cel portfela projektów zwinnych musi równoważyć $\mathrm{z}$ jednej strony dążenie do realizacji celów strategicznych, zaś z drugiej koncentrację na kliencie i zaspokajaniu jego potrzeb (Sweetman, Conboy, 2013).

\section{Metoda badawcza}

$\mathbf{Z}$ astosowaną metodą badawczą była analiza danych ilościowych. Dane empiryczne zaczerpnięte zostały z branżowych raportów „Annual State of Agile Report”, publikowanych corocznie przez firmę „Vision One" na stronie https://stateofagile.com/home. W toku analizy wykorzystano dane zawarte $\mathrm{w}$ raportach za lata 2010-2019. Nie uwzględniono danych z raportów opublikowanych w latach 2009 i 2008, z uwagi na odmienny niż w późniejszych raportach sposób prowadzenia badań oraz prezentacji wyników.

Zasięg terytorialny prowadzonych przez firmę „Vision One” badań miał charakter globalny. Liczba respondentów biorących udział w ankiecie liczyła średnio powyżej 3 tys. osób na przestrzeni badanego okresu (tab. 1). Badani mieli możliwość wskazania odpowiedzi na więcej niż jedno pytanie, zatem analizowane raporty zawierają procent wskazań respondentów. Pozwoliło to na ich tabelaryczne zestawienie oraz obliczenie podstawowych statystyk opisowych, tj. średniej arytmetycznej, odchylenia standardowego oraz mediany (Dyduch, 2016).

\section{Wyniki badań}

A naliza przesłanek, które stoją za stosowaniem przez przedsiębiorstwa podejścia adaptacyjnego, umoż- liwia ich analizę na trzech poziomach: strategicznym, taktycznym oraz operacyjnym (tab. 2). Na poziomie strategicznym respondenci wskazywali na zwiększenie zdolności organizacji do działania w warunkach zmienności otoczenia (średnia 68\% wskazań) oraz poprawę produktywności organizacji (średnia 62\% wskazań). Analiza trendu wskazuje, że przesłanki te tracą w opinii respondentów, na znaczeniu. Pierwsza z nich była wskazywana jako powód zastosowania podejścia adaptacyjnego przez $82 \%$ respondentów w roku 2010 i 63\% w roku 2019. Druga, tj. poprawa produktywności organizacji, była wskazywana przez $80 \%$ respondentów w roku 2010 i 51\% w roku 2019. Przeprowadzone analizy wskazują, że najważniejszymi, w opinii respondentów powodami stosowania podejścia adaptacyjnego są przesłanki o charakterze operacyjnym, tj. przyspieszenie dostaw oprogramowania (średnia 71\% wskazań) oraz poprawa jakości tworzonego oprogramowania (średnia 54\% wskazań). Przyśpieszenie dostaw oprogramowania jest przesłanką, której znaczenie w całym badanym okresie respondenci oceniają w sposób podobny (odchylenie standardowe 6\%, mediana 74\%).

Najważniejszą korzyścią (tab. 3), jaką odnoszą przedsiębiorstwa, stosując podejście adaptacyjne, jest w opinii badanych respondentów umiejętność zarządzania zmieniającymi się priorytetami (średnia $83 \%$ wskazań). Jednakże znaczenie tej korzyści dla przedsiębiorstw jest coraz mniejsze (87\% wskazań w roku 2010 oraz $70 \%$ w roku 2019). Istotną korzyścią, jaką odnosi organizacja, stosując podejście adaptacyjne do zarządzania projektami, jest skrócenie czasu dotarcia z produktem na rynek (średnia 73\% wskazań). Pozostałe wskazywane przez respondentów korzyści dotyczą projektu oraz realizującego go zespołu. Są nimi poprawa widoczności wyników projektu (średnia 77\% wskazań), zwiększona produktywność zespołu (średnia 75\% wskazań) oraz poprawa jego morale (średnia $74 \%$ wskazań).

Kolejnym analizowanym aspektem był zakres stosowania metod skalowania zwinnego (tab. 4). Metody te ppozwalają na wykorzystanie adaptacyjnego podejścia do zarządzania projektami na poziomie całej organizacji, nie tylko projektu. W tym przypadku okres analizy obejmował lata 2014-2019, z uwagi na fakt, że zagadnienia te, jako stosunkowo nowe, badane były dopiero od roku 2014.

Najważniejszą i najczęściej stosowaną metodą skalowania zwinnego jest Scaled Agile Framework. Średnia wskazań dla tej metody skalowania zwinnego to $28 \%$ respondentów. Drugą najczęściej stosowaną metodą jest Scrum of Scrums. Analiza wskazań respondentów na przestrzeni badanego okresu, pozwala stwierdzić rosnącą systematycznie popularność Scaled Agile Framework oraz malejącą Scrum of Scrums (tab. 4). Znaczną część stosowanych rozwiązań stanowią metody będące rozwiązaniami wypracowanymi na potrzeby konkretnych przedsiębiorstw (średnia 16\% wskazań). Jednakże częstotliwość ich wykorzystania maleje systematycznie na przestrzeni badanego okresu (25\% wskazań w roku 2010 oraz $8 \%$ w roku 2019). Pozostałe wskazywane metody pozwalające na skalowanie rozwiązań zwinnych na poziom organizacji, tj. Enterprise Scrum, Disciplined Agile 
Tabela 1. Liczba respondentów biorących udziat w ankiecie firmy „Vision One”

\begin{tabular}{|l|l|l|l|l|l|l|l|l|l|l|}
\cline { 2 - 11 } \multicolumn{1}{c|}{} & 2010 & 2011 & 2012 & 2013 & 2014 & $\mathbf{2 0 1 5}$ & $\mathbf{2 0 1 6}$ & $\mathbf{2 0 1 7}$ & $\mathbf{2 0 1 8}$ & $\mathbf{2 0 1 9}$ \\
\hline Próba badawcza (liczba respondentów) & 4770 & 6042 & 4048 & 3501 & 3925 & 3880 & b.d. & 1492 & 1319 & 1121 \\
\hline
\end{tabular}

Źródło: opracowanie wtasne na podstawie: Annual State of Agile Report (lata 2010-2019)

Tabela 2. Przesłanki stosowania podejścia adaptacyjnego do zarządzania projektami

\begin{tabular}{|c|c|c|c|c|c|c|c|c|c|c|c|c|c|}
\hline & Średnia & SD & Mediana & 2010 & 2011 & 2012 & 2013 & 2014 & 2015 & 2016 & 2017 & 2018 & 2019 \\
\hline $\begin{array}{l}\text { Zwiększenie } \\
\text { zdolności organizacji } \\
\text { do zarządzania } \\
\text { zmieniającymi się } \\
\text { priorytetami }\end{array}$ & $68 \%$ & $10 \%$ & $64 \%$ & $82 \%$ & $83 \%$ & $78 \%$ & $71 \%$ & $56 \%$ & $56 \%$ & $61 \%$ & $64 \%$ & $62 \%$ & $63 \%$ \\
\hline $\begin{array}{l}\text { Poprawa } \\
\text { produktywności } \\
\text { organizacji }\end{array}$ & $62 \%$ & $12 \%$ & $55 \%$ & $80 \%$ & $80 \%$ & $72 \%$ & $74 \%$ & $53 \%$ & $55 \%$ & $53 \%$ & $55 \%$ & $51 \%$ & $51 \%$ \\
\hline $\begin{array}{l}\text { Doskonalenie i rozwój } \\
\text { biznesu }\end{array}$ & $53 \%$ & $11 \%$ & $50 \%$ & $63 \%$ & $65 \%$ & $64 \%$ & $67 \%$ & $40 \%$ & $44 \%$ & $42 \%$ & $49 \%$ & $50 \%$ & $47 \%$ \\
\hline $\begin{array}{l}\text { Zwiększenie zdolności } \\
\text { do zarządzania } \\
\text { rozproszonymi } \\
\text { zespołami }\end{array}$ & $22 \%$ & $4 \%$ & $21 \%$ & $22 \%$ & $26 \%$ & $29 \%$ & $29 \%$ & $20 \%$ & $21 \%$ & $20 \%$ & $17 \%$ & $19 \%$ & $21 \%$ \\
\hline $\begin{array}{l}\text { Przyspieszenie dostaw } \\
\text { oprogramowania }\end{array}$ & $71 \%$ & $6 \%$ & $74 \%$ & $78 \%$ & $77 \%$ & $73 \%$ & $75 \%$ & $59 \%$ & $62 \%$ & $69 \%$ & $75 \%$ & $74 \%$ & $71 \%$ \\
\hline $\begin{array}{l}\text { Poprawa jakości } \\
\text { tworzonego } \\
\text { oprogramowania }\end{array}$ & $54 \%$ & $13 \%$ & $47 \%$ & $73 \%$ & $71 \%$ & $67 \%$ & $66 \%$ & $46 \%$ & $47 \%$ & $43 \%$ & $46 \%$ & $43 \%$ & $42 \%$ \\
\hline $\begin{array}{l}\text { Poprawa łatwości } \\
\text { użytkowania } \\
\text { oprogramowania }\end{array}$ & $32 \%$ & $15 \%$ & $22 \%$ & $52 \%$ & $50 \%$ & $47 \%$ & $47 \%$ & $22 \%$ & $22 \%$ & $18 \%$ & $18 \%$ & $21 \%$ & $18 \%$ \\
\hline
\end{tabular}

Źródło: opracowanie wtasne na podstawie: Annual State of Agile Report (lata 2010-2019)

Tabela 3. Korzyści z zastosowania podejścia adaptacyjnego do zarządzania projektami

\begin{tabular}{|c|c|c|c|c|c|c|c|c|c|c|c|c|c|}
\hline & Średnia & SD & Mediana & 2010 & 2011 & 2012 & 2013 & 2014 & 2015 & 2016 & 2017 & 2018 & 2019 \\
\hline $\begin{array}{l}\text { Umiejętność } \\
\text { zarządzania } \\
\text { zmieniającymi się } \\
\text { priorytetami }\end{array}$ & $83 \%$ & $9 \%$ & $87 \%$ & $87 \%$ & $84 \%$ & $90 \%$ & $92 \%$ & $87 \%$ & $87 \%$ & $88 \%$ & $71 \%$ & $69 \%$ & $70 \%$ \\
\hline Widoczność projektu & $77 \%$ & $8 \%$ & $80 \%$ & $78 \%$ & $77 \%$ & $84 \%$ & $86 \%$ & $82 \%$ & $84 \%$ & $83 \%$ & $66 \%$ & $65 \%$ & $65 \%$ \\
\hline $\begin{array}{l}\text { Zwiększona } \\
\text { produktywność zespołu }\end{array}$ & $75 \%$ & $11 \%$ & $79 \%$ & $74 \%$ & $75 \%$ & $85 \%$ & $87 \%$ & $84 \%$ & $85 \%$ & $83 \%$ & $61 \%$ & $61 \%$ & $58 \%$ \\
\hline $\begin{array}{l}\text { Zwiększone morale } \\
\text { zespołu }\end{array}$ & $74 \%$ & $10 \%$ & $76 \%$ & $71 \%$ & $72 \%$ & $84 \%$ & $86 \%$ & $79 \%$ & $81 \%$ & $81 \%$ & $61 \%$ & $64 \%$ & $59 \%$ \\
\hline $\begin{array}{l}\text { Skrócenie czasu } \\
\text { dostawy (dotarcia na } \\
\text { rynek) }\end{array}$ & $73 \%$ & $9 \%$ & $74 \%$ & $70 \%$ & $71 \%$ & $79 \%$ & $83 \%$ & $77 \%$ & $80 \%$ & $81 \%$ & $62 \%$ & $63 \%$ & $60 \%$ \\
\hline $\begin{array}{l}\text { Lepsza współpraca } \\
\text { działów biznesowych } \\
\text { z IT }\end{array}$ & $72 \%$ & $7 \%$ & $72 \%$ & $68 \%$ & $68 \%$ & $79 \%$ & $82 \%$ & $75 \%$ & $77 \%$ & $76 \%$ & $65 \%$ & $64 \%$ & $65 \%$ \\
\hline $\begin{array}{l}\text { Konserwacja } \\
\text { oprogramowania }\end{array}$ & $57 \%$ & $17 \%$ & $62 \%$ & $56 \%$ & $60 \%$ & $74 \%$ & $75 \%$ & $68 \%$ & $70 \%$ & $64 \%$ & $33 \%$ & $34 \%$ & $35 \%$ \\
\hline $\begin{array}{l}\text { Redukcja kosztów } \\
\text { projektu }\end{array}$ & $37 \%$ & $14 \%$ & $34 \%$ & $39 \%$ & $49 \%$ & - & - & - & - & $56 \%$ & $22 \%$ & $28 \%$ & $26 \%$ \\
\hline
\end{tabular}

Źródło: opracowanie wtasne na podstawie: Annual State of Agile Report (lata 2010-2019) 
Tabela 4. Najczęściej wykorzystane metody skalowania zwinnego

\begin{tabular}{|l|c|c|c|c|c|c|c|c|c|}
\hline & Średnia & SD & Mediana & $\mathbf{2 0 1 4}$ & $\mathbf{2 0 1 5}$ & $\mathbf{2 0 1 6}$ & $\mathbf{2 0 1 7}$ & $\mathbf{2 0 1 8}$ & $\mathbf{2 0 1 9}$ \\
\hline Metody stworzone wewnątrz & $16 \%$ & $8 \%$ & $13 \%$ & $25 \%$ & $23 \%$ & $13 \%$ & $10 \%$ & $8 \%$ & - \\
\hline Scaled Agile Framework (SAFe) & $28 \%$ & $5 \%$ & $29 \%$ & $19 \%$ & $27 \%$ & $28 \%$ & $29 \%$ & $30 \%$ & $35 \%$ \\
\hline Nie wiem / inne metody & $23 \%$ & $5 \%$ & $22 \%$ & - & - & - & $22 \%$ & $19 \%$ & $28 \%$ \\
\hline Scrum of Scrums & $37 \%$ & $27 \%$ & $23 \%$ & $69 \%$ & $72 \%$ & $27 \%$ & $19 \%$ & $16 \%$ & $16 \%$ \\
\hline Lean Management & $8 \%$ & $7 \%$ & $4 \%$ & $18 \%$ & $17 \%$ & $4 \%$ & $3 \%$ & $3 \%$ & $4 \%$ \\
\hline Enterprise Scrum & $6 \%$ & $3 \%$ & $4 \%$ & $9 \%$ & $9 \%$ & - & $3 \%$ & $3 \%$ & $4 \%$ \\
\hline Disciplined Agile Delivery (DAD) & $4 \%$ & $2 \%$ & $4 \%$ & $4 \%$ & $4 \%$ & $1 \%$ & $5 \%$ & $7 \%$ & $4 \%$ \\
\hline Large Scale Scrum (LeSS) & $4 \%$ & $1 \%$ & $4 \%$ & $3 \%$ & $6 \%$ & $3 \%$ & $5 \%$ & $3 \%$ & $4 \%$ \\
\hline Nexus & $2 \%$ & $1 \%$ & $2 \%$ & - & - & $1 \%$ & $1 \%$ & $2 \%$ & $3 \%$ \\
\hline Agile Portfolio Management (APM) & $5 \%$ & $3 \%$ & $4 \%$ & $9 \%$ & $9 \%$ & $4 \%$ & $3 \%$ & $3 \%$ & $3 \%$ \\
\hline Recipes for Agile Governance in the Enterprise & $1 \%$ & $0 \%$ & $1 \%$ & $1 \%$ & $1 \%$ & $1 \%$ & $0 \%$ & $1 \%$ & $1 \%$ \\
\hline
\end{tabular}

Źródło: opracowanie własne na podstawie: Annual State of Agile Report (lata 2014-2019)

Tabela 5. Najczęściej wykorzystane metodyki zwinne

\begin{tabular}{|l|c|c|c|c|c|c|c|c|c|c|c|c|c|}
\hline & Średnia & SD & Mediana & $\mathbf{2 0 1 0}$ & $\mathbf{2 0 1 1}$ & $\mathbf{2 0 1 2}$ & $\mathbf{2 0 1 3}$ & $\mathbf{2 0 1 4}$ & $\mathbf{2 0 1 5}$ & $\mathbf{2 0 1 6}$ & $\mathbf{2 0 1 7}$ & $\mathbf{2 0 1 8}$ & $\mathbf{2 0 1 9}$ \\
\hline Spotify model & $1 \%$ & - & $1 \%$ & - & - & - & - & - & - & - & $1 \%$ & - & - \\
\hline SCRUM & $56 \%$ & $2 \%$ & $56 \%$ & $58 \%$ & $52 \%$ & $54 \%$ & $55 \%$ & $56 \%$ & $58 \%$ & $58 \%$ & $56 \%$ & $54 \%$ & $58 \%$ \\
\hline SCRUMBAN & $7 \%$ & $2 \%$ & $7 \%$ & $3 \%$ & $3 \%$ & $7 \%$ & $7 \%$ & $6 \%$ & $7 \%$ & $8 \%$ & $8 \%$ & $8 \%$ & $10 \%$ \\
\hline Inne metody / Nie wiem & $12 \%$ & $4 \%$ & $13 \%$ & $13 \%$ & $17 \%$ & $13 \%$ & $10 \%$ & $15 \%$ & $14 \%$ & $13 \%$ & $9 \%$ & $6 \%$ & $7 \%$ \\
\hline SCRUM XP Hybrid & $11 \%$ & $3 \%$ & $10 \%$ & $17 \%$ & $14 \%$ & $11 \%$ & $11 \%$ & $10 \%$ & $10 \%$ & $10 \%$ & $6 \%$ & $10 \%$ & $8 \%$ \\
\hline $\begin{array}{l}\text { Other Hybrid / Multiple } \\
\text { Methdologies }\end{array}$ & $9 \%$ & $3 \%$ & $9 \%$ & $5 \%$ & $9 \%$ & $9 \%$ & $10 \%$ & $8 \%$ & $8 \%$ & $8 \%$ & $14 \%$ & $14 \%$ & $9 \%$ \\
\hline KANBAN & $5 \%$ & $1 \%$ & $5 \%$ & - & $3 \%$ & $4 \%$ & $5 \%$ & $5 \%$ & $5 \%$ & $5 \%$ & $5 \%$ & $5 \%$ & $7 \%$ \\
\hline $\begin{array}{l}\text { Extreme Programming } \\
\text { (XP) }\end{array}$ & $2 \%$ & $1 \%$ & $1 \%$ & $4 \%$ & $2 \%$ & $2 \%$ & $1 \%$ & $1 \%$ & $1 \%$ & $1 \%$ & $1 \%$ & $1 \%$ & $1 \%$ \\
\hline Lean Startup & $1 \%$ & $1 \%$ & $1 \%$ & $2 \%$ & - & - & - & - & - & $1 \%$ & $1 \%$ & $2 \%$ & $1 \%$ \\
\hline
\end{tabular}

Źródło: opracowanie własne na podstawie: Annual State of Agile Report (lata 2010-2019)

Tabela 6. Miary sukcesu projektów zwinnych

\begin{tabular}{|l|c|c|c|c|c|c|c|c|c|}
\hline & Średnia & SD & Mediana & $\mathbf{2 0 1 4}$ & $\mathbf{2 0 1 5}$ & $\mathbf{2 0 1 6}$ & $\mathbf{2 0 1 7}$ & $\mathbf{2 0 1 8}$ & $\mathbf{2 0 1 9}$ \\
\hline Prędkość & $50 \%$ & $13 \%$ & $50 \%$ & $59 \%$ & $57 \%$ & $67 \%$ & $42 \%$ & $38 \%$ & $37 \%$ \\
\hline Wypalanie iteracji & $38 \%$ & $14 \%$ & $39 \%$ & $51 \%$ & $51 \%$ & $51 \%$ & $27 \%$ & $25 \%$ & $24 \%$ \\
\hline Wypalanie wydania & $30 \%$ & $11 \%$ & $30 \%$ & $39 \%$ & $41 \%$ & $38 \%$ & $22 \%$ & $19 \%$ & $18 \%$ \\
\hline Zadowolenie klienta / użytkownika & $37 \%$ & $10 \%$ & $37 \%$ & $28 \%$ & $29 \%$ & $28 \%$ & $46 \%$ & $46 \%$ & $45 \%$ \\
\hline $\begin{array}{l}\text { Planowane vs. zrealizowane } \\
\text { historyjki w iteracji }\end{array}$ & $33 \%$ & $4 \%$ & $33 \%$ & $35 \%$ & $37 \%$ & $37 \%$ & $30 \%$ & $29 \%$ & $31 \%$ \\
\hline Planowany vs. wykonany koszt & $27 \%$ & $5 \%$ & $27 \%$ & $22 \%$ & $23 \%$ & $22 \%$ & $31 \%$ & $31 \%$ & $31 \%$ \\
\hline Dostarczona wartość biznesowa & $32 \%$ & $13 \%$ & $33 \%$ & $19 \%$ & $21 \%$ & $23 \%$ & $43 \%$ & $42 \%$ & $46 \%$ \\
\hline Zmiana zakresu w wydaniu & $13 \%$ & $4 \%$ & $13 \%$ & $16 \%$ & $17 \%$ & $16 \%$ & $9 \%$ & $8 \%$ & $9 \%$ \\
\hline
\end{tabular}

Źródto: opracowanie własne na podstawie: Annual State of Agile Report (lata 2014-2019) 
Delivery (DAD), Large Scale Scrum (LeSS) oraz Nexus, są stosunkowo rzadko wykorzystywane w badanych organizacjach (odpowiednio średnio $6 \%, 4 \%, 4 \%$ oraz $2 \%$ wskazań respondentów).

Analizę preferencji respondentów w zakresie wykorzystywanych metodyk zwinnych zawiera tabela 5 . Zgromadzone dane wskazują jednoznacznie, że najczęściej wykorzystywaną metodyką jest SCRUM. Ponad połowa badanych respondentów deklaruje stosowanie tej właśnie metodyki (średnia 56\% wskazań respondentów). Popularność tej metodyki wśród badanych przedsiębiorstw kształtuje się bardzo stabilnie na przestrzeni całego badanego okresu (odchylenie standardowe 2\%). Dużą popularnością cieszy się również metodyka SCRUM XP Hybrid (średnia 11\% wskazań) oraz metodyki łączące w sobie elementy innych metodyk (średnia $9 \%$ wskazań). Podobna liczba respondentów deklaruje korzystanie $\mathrm{z}$ innych metodyk zwinnych lub nie wie, $\mathrm{z}$ jakiej obecnie korzysta przedsiębiorstwo, w którym są zatrudnieni (średnia wskazań $12 \%$ ).

Oprócz metodyk opisywanych powyżej widoczny jest wzrost zainteresowania badanych przedsiębiorstw japońską metodą KANBAN, stosowaną dotąd powszechnie w obszarze zarządzania produkcją (średnia 5\% wskazań). Często stosowana jest również metodyka SCRUMBAN, będaca połączeniem metody KANBAN i metodyki SCRUM, która łączy najlepsze z punktu widzenia zarządzania projektami zwinnymi elementy obu z nich (średnio 7\% wskazań). Wzrost ten widoczny jest na rysunku 1.

Analizę tego, w jaki sposób dokonuje się pomiaru sukcesu projektów zarządzanych za pomocą zwinnych metodyk zarządzania zawiera tabela 6 .

Analiza najczęściej stosowanych miar sukcesu dla projektów zwinnych pozwala stwierdzić, że następuje odejście od miar bardzo precyzyjnych, zorientowanych na produktywność zespołu projektowego (tj. prędkość zespołu, tempo wypalania iteracji czy wydania). Znaczenie tych mierników na przestrzeni analizowanego okresu systematycznie maleje: dla prędkości zespołu z 59\% wskazań w roku 2014 do $37 \%$ wskazań w roku 2019, dla tempa wypalania iteracji z 51\% w roku 2014 do $24 \%$ w roku
2019 oraz tempa spalania wydania z 39 do $18 \%$. Z kolei na znaczeniu zyskują mierniki o charakterze kompleksowym, za pomocą których mierzyć można zadowolenie klienta (średnia wskazań 37\%) oraz wpływ projektu na rozwój biznesu (średnia wskazań 32\%). Rośnie również według respondentów znaczenie mierników opisujących efektywność wykorzystania budżetu projektu (średnia wskazań $27 \%$ ).

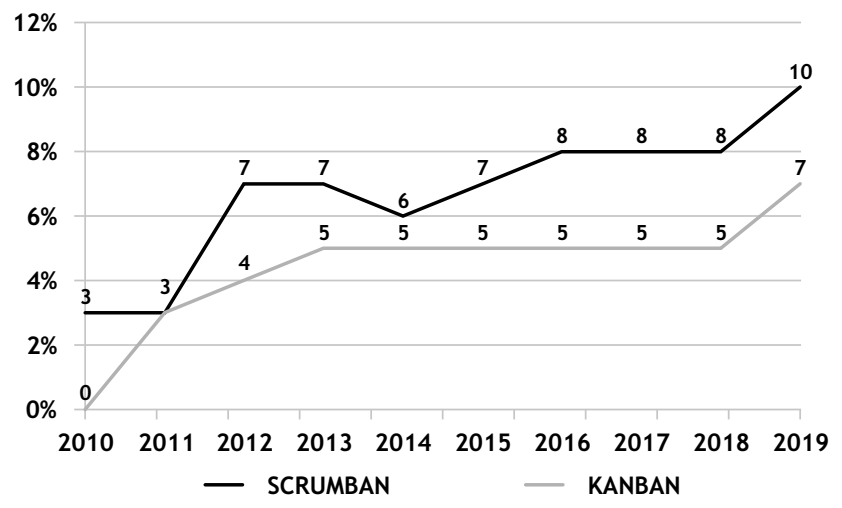

Rys. 1. Metodyki zwinne zyskujące na znaczeniu Źródto: opracowanie wtasne na podstawie: Annual State of Agile Report (lata 2014-2019)

Kolejny aspekt prowadzonych prac to analiza najczęściej wykorzystywanych przez zespoły projektowe technik. W badanych przedsiębiorstwach najczęściej wykorzystywane są rozwiązania specyficzne dla metodyk zwinnych, tj. planowanie iteracji, codzienne spotkania przeprowadzane $\mathrm{w}$ trakcie iteracji oraz retrospektywa po zakończeniu iteracji. Zespół projektowy, wykorzystując te techniki, może w sposób zaplanowany rozwijać produkt, generując oczekiwany przyrost („increment”). Od roku 2016 respondenci wskazują również na przegląd iteracji jako uzupełnienie technik poprzednio stosowanych w ramach iteracji. Rozróżnienie przeglądu iteracji oraz retrospektywy ma kluczowy charakter. W ramach przeglądu iteracji analizowane są kwestie związane z produktem i sposobem jego powstawania, natomiast w przypadku retrospektywy, analizowane są kwestie związane

Tabela 7. Najczęściej wykorzystywane narzędzia w podejściu adaptacyjnym

\begin{tabular}{|l|c|c|c|c|c|c|c|c|c|c|c|c|}
\hline & Średnia & SD & Mediana & $\mathbf{2 0 1 1}$ & $\mathbf{2 0 1 2}$ & $\mathbf{2 0 1 3}$ & $\mathbf{2 0 1 4}$ & $\mathbf{2 0 1 5}$ & $\mathbf{2 0 1 6}$ & $\mathbf{2 0 1 7}$ & $\mathbf{2 0 1 8}$ & $\mathbf{2 0 1 9}$ \\
\hline Tablica KANBAN & $58 \%$ & $18 \%$ & $63 \%$ & $27 \%$ & $37 \%$ & $43 \%$ & $52 \%$ & $63 \%$ & $69 \%$ & $74 \%$ & $75 \%$ & $76 \%$ \\
\hline Tablica zadań & $74 \%$ & $6 \%$ & $75 \%$ & $67 \%$ & $77 \%$ & $81 \%$ & $79 \%$ & $82 \%$ & $75 \%$ & $71 \%$ & $70 \%$ & $66 \%$ \\
\hline Arkusz & $68 \%$ & $3 \%$ & $67 \%$ & $67 \%$ & $69 \%$ & $68 \%$ & $72 \%$ & $74 \%$ & $67 \%$ & $65 \%$ & $66 \%$ & $64 \%$ \\
\hline Wiki & $66 \%$ & $4 \%$ & $65 \%$ & $65 \%$ & $72 \%$ & $71 \%$ & $68 \%$ & $68 \%$ & $62 \%$ & $62 \%$ & $62 \%$ & $60 \%$ \\
\hline Planowanie produktów & $51 \%$ & $1 \%$ & $51 \%$ & - & - & - & - & - & - & - & $50 \%$ & $51 \%$ \\
\hline Refaktoring & $28 \%$ & $5 \%$ & $29 \%$ & $31 \%$ & $32 \%$ & $33 \%$ & $29 \%$ & $30 \%$ & $25 \%$ & $19 \%$ & $22 \%$ & $26 \%$ \\
\hline $\begin{array}{l}\text { Narzędzia do zarządzania } \\
\text { pomysłami klientów }\end{array}$ & $19 \%$ & $2 \%$ & $19 \%$ & $18 \%$ & $20 \%$ & $21 \%$ & $22 \%$ & $21 \%$ & $16 \%$ & $16 \%$ & $18 \%$ & $19 \%$ \\
\hline
\end{tabular}

Źródło: opracowanie własne na podstawie: Annual State of Agile Report (lata 2011-2019) 
$\mathrm{z}$ funkcjonowaniem zespołu projektowego (Scrum Guide, 2020). Kolejnym aspektem prowadzonych analiz był sposób wykorzystywania przez zespół projektowy narzędzi zwinnego zarządzania projektami (tab. 7). Zagadnienie to pojawia się w raportach, począwszy od roku 2011. Najczęściej wykorzystywanym narzędziem są tablice zadań oraz tablice KANBAN (średnia odpowiednio 74\% i 58\% wskazań) oraz różnego rodzaju arkusze (średnia $68 \%$ wskazań). Narzędzia te są wykorzystywane głównie do planowania oraz monitorowania postępu prac zespołu projektowego w ramach iteracji bądź wydania. Wydaje się, że respondenci w wielu przypadkach uznają te narzędzia jako narzędzia o charakterze komplementarnym.

Respondenci w analizowanych raportach wskazują również, że narzędzia informatyczne w sposób kompleksowy wspierają realizowanie projektów zwinnych (tab. 8). Do najczęściej stosowanych respondenci zaliczyli Atlassian JIRA (47\% wskazań respondentów) oraz narzędzia pakietu MS Office, tj. MS Excel (średnio 56\% wskazań) oraz MS Project (średnio 32\% wskazań). Widoczny jest jednak trend świadczący o odchodzeniu od tych narzędzi informatycznych. Zwłaszcza mocno widoczne jest to w przypadku MS Project (30\% wskazań w roku 2010 i 9\% wskazań w roku 2019). Z kolei widoczny jest systematyczny wzrost, jeżeli chodzi o wykorzystywanie w badanych przedsiębiorstwach pakietu Atlassian JIRA - od 29\% wskazań w roku 2010 do $67 \%$ wskazań respondentów w roku 2019.

\section{Dyskusja wyników badań}

A naliza zgromadzonych danych pozwala sformułować kilka obserwacji. Jeżeli chodzi o powody zainteresowania przedsiębiorstw podejściem zwinnym, to dominują przesłanki o charakterze operacyjnym (głównie przyśpieszenie dostaw oprogramowania), natomiast uzyskane korzyści mają charakter strategiczny. Podstawową korzyścią o takim charakterze była umiejętność zarządzania zmieniającymi się priorytetami, co jest de facto istotą podejścia adaptacyjnego. Pozwala to stwierdzić, że badane przedsiębiorstwa interesują się podejściem adaptacyjnym, mając na uwadze korzyści krótkoterminowe, natomiast stosując to podejście, uzyskują w dłuższej perspektywie czasu dodatkowe korzyści warunkujące ich rozwój, tj. adaptację do zmieniających się warunków rynkowych.

Scaled Agile Framework to najczęściej wykorzystywana metoda pozwalająca na skalowanie rozwiązań zwinnych na poziomie organizacji. Inne rozwiązania, szczególnie bazujące wprost na skalowaniu rozwiązań stosowanych na poziomie projektu, tj. Scrum of Scrums, tracą na znaczeniu bądź ich rozpoznawalność jest niewielka (Nexus). Duża popularność Scaled Agile Framework jest efektem, z jednej strony kompleksowości rozwiązania, z drugiej elastyczności założeń, które pozwalają je dostosować do potrzeb organizacji (Leffingwell, 2007). SAFe pozwala stosować rozwiązania na poziomie projektu, programu oraz portfela (Wyrozębski, 2020). Analiza danych zawartych w raportach potwierdza również, że duża część metod zwinnych stosowanych na poziomie organizacji to wypracowane we własnym zakresie przez przedsiębiorstwa metody będące zwykle kompilacją kilku różnych dostępnych rozwiązań (Stettina, Hörz, 2015). Stanowi to odpowiedź na formułowane pod względem metody SAFe zastrzeżenia dotyczące jej założeń, które każą ją bardziej traktować jako hybrydową metodę skalowania, nie zaś stricte zwinną.

SCRUM jest najczęściej stosowaną metodyką w przypadku projektów realizowanych przy użyciu podejścia adaptacyjnego. Wydaje się, że siłą tej metodyki jest jej prostota oraz adaptowalność (Scrum Guide, 2020). Ogólnie sformułowane ramy działania uczestników projektów wsparte są w przypadku tej metodyki spójnym zestawem zasad i praktyk (Schwaber, Sutherland, 2017). Zastosowane założenia powodują, że łatwo ją do-

Tabela 8. Najczęściej wykorzystywane narzędzia informatyczne w podejściu adaptacyjnym

\begin{tabular}{|c|c|c|c|c|c|c|c|c|c|c|c|c|c|}
\hline & Średnia & SD & Mediana & 2010 & 2011 & 2012 & 2013 & 2014 & 2015 & 2016 & 2017 & 2018 & 2019 \\
\hline Microsoft Azure DevOps & $23 \%$ & - & $23 \%$ & - & - & - & - & - & - & - & - & - & $23 \%$ \\
\hline Atlassian JIRA Align & $5 \%$ & - & $5 \%$ & - & - & - & - & - & - & - & - & - & $5 \%$ \\
\hline Atlassian JIRA & $47 \%$ & $14 \%$ & $48 \%$ & $29 \%$ & $35 \%$ & $33 \%$ & $36 \%$ & $45 \%$ & $51 \%$ & $53 \%$ & $58 \%$ & $65 \%$ & $67 \%$ \\
\hline Microsoft Excel & $56 \%$ & $10 \%$ & $56 \%$ & $52 \%$ & $61 \%$ & $69 \%$ & $66 \%$ & $68 \%$ & $60 \%$ & $46 \%$ & $46 \%$ & $48 \%$ & $40 \%$ \\
\hline Microsoft Project & $32 \%$ & $13 \%$ & $32 \%$ & $30 \%$ & $36 \%$ & $48 \%$ & $48 \%$ & $46 \%$ & $33 \%$ & $20 \%$ & $21 \%$ & $24 \%$ & $9 \%$ \\
\hline Google Docs & $19 \%$ & $3 \%$ & $19 \%$ & $16 \%$ & $22 \%$ & $20 \%$ & $20 \%$ & $24 \%$ & $18 \%$ & $14 \%$ & $17 \%$ & $19 \%$ & $19 \%$ \\
\hline VersionOne & $28 \%$ & $10 \%$ & $31 \%$ & $36 \%$ & $37 \%$ & $36 \%$ & $41 \%$ & $33 \%$ & $28 \%$ & $20 \%$ & $20 \%$ & $14 \%$ & $12 \%$ \\
\hline Bugzilla & $12 \%$ & $7 \%$ & $12 \%$ & $13 \%$ & $14 \%$ & $22 \%$ & $21 \%$ & $19 \%$ & $10 \%$ & $5 \%$ & $4 \%$ & $5 \%$ & $3 \%$ \\
\hline LeanKit & $4 \%$ & $1 \%$ & $4 \%$ & - & $2 \%$ & $4 \%$ & $5 \%$ & $6 \%$ & $5 \%$ & $5 \%$ & $4 \%$ & $4 \%$ & $2 \%$ \\
\hline Axosoft & $2 \%$ & $1 \%$ & $2 \%$ & - & - & - & - & $2 \%$ & $2 \%$ & $1 \%$ & $1 \%$ & $2 \%$ & $1 \%$ \\
\hline Hansoft & $1 \%$ & $0 \%$ & $1 \%$ & - & - & - & - & $1 \%$ & $1 \%$ & $1 \%$ & $1 \%$ & $1 \%$ & $1 \%$ \\
\hline
\end{tabular}

Źródło: opracowanie wtasne na podstawie: Annual State of Agile Report (lata 2010-2019) 
stosować do potrzeb konkretnej organizacji (Schwaber, Beedle, 2002). Analiza danych zawartych w raportach wskazuje na dużą popularność rozwiązań (tj. XP Hybrid czy SCRUM XP Hybrid), które łączą elementy różnych metodyk. Jest to spowodowane faktem, że przedsiębiorstwa poszukują rozwiązania najlepiej dopasowanego do ich specyficznych potrzeb. Podobne zjawisko miało miejsce w podejściu tradycyjnym, gdzie dostępne metodyki kaskadowe byly modyfikowane do potrzeb organizacji bądź bazujące na nich organizacje opracowywały swoje własne rozwiązania. Dzięki temu, choć metodyki zwinne zwykle utożsamia się z projektami informatycznymi, to metodyka SCRUM (oraz jej odmiany) jest często stosowana również przez przedsiębiorstwa $z$ innych branż do realizowania projektów innych niż informatyczne (Serrador, Pinto, 2015).

Zmienia się rozumienie i sposób pomiaru sukcesu projektu w podejściu zwinnym. Początkowo sukces projektu mierzony był poprzez prędkość zespołu oraz tempo realizowania zaplanowanych $\mathrm{w}$ iteracji zadań (wypalanie iteracji). Analiza danych wskazuje, że obecnie zmienia się rozumienie sukcesu projektu zwinnego, bowiem coraz powszechniej wykorzystuje się mierniki pozwalające mierzyć go bardziej kompleksowo, np. poprzez pomiar zadowolenia klienta oraz wpływu, jaki ma projekt na rozwój biznesu organizacji. Widoczne jest zatem przesunięcie sposobu pomiaru rezultatów projektów zwinnych od miar zorientowanych na tempo pracy zespołu, w kierunku miar pozwalających mierzyć także pozostałe istotne aspekty sukcesu projektu (którymi są satysfakcja klienta, zespołu czy rozwój biznesu). Stwierdzić można zatem, że postrzeganie sukcesu projektów zwinnych, początkowo inne, ewoluuje w tym samym kierunku co rozumienie sukcesu projektów realizowanych zgodnie z podejściem tradycyjnym (Andersen i in., 2006).

Powszechne zastosowanie metodyki SCRUM powoduje również, że respondenci, jako najczęściej wykorzystywane techniki wskazują: planowanie iteracji, codzienne spotkania zespołu, przegląd iteracji oraz retrospektywę. W ramach przeglądu iteracji analizowane są zagadnienia związane $\mathrm{z}$ produktem, natomiast $\mathrm{w}$ przypadku retrospektywy z działaniem zespołu projektowego (Schwaber, Sutherland, 2017). Ma to również swoje odzwierciedlenie $\mathrm{w}$ wykorzystywanych przez zespoły projektowe narzędziach. Najbardziej popularne są tablice zadań ( $w$ tym tablice KANBAN) oraz różnego rodzaju arkusze pozwalające wizualizować postęp zespołu projektowego. Jeżeli chodzi o wsparcie informatyczne zespołu projektowego w podejściu zwinnym, to dalej dość powszechnie wykorzystywane są narzędzia pakietu MS Office, w tym w szczególności MS Excel. Natomiast jeżeli chodzi o wsparcie informatyczne rozwiązań o bardziej kompleksowym charakterze, to najczęściej wykorzystywany jest pakiet Atlassian JIRA. Popularność tego oprogramowania rośnie systematycznie, co wskazuje, że odejście w projektach zwinnych od prostych narzędzi dostępnych $\mathrm{w}$ pakiecie MS Office spowodowane jest rosnącymi oczekiwaniami przedsiębiorstw odnośnie do monitowania postępu prac w tego typu projektach.

\section{Podsumowanie}

$\mathbf{P}$ rzeprowadzone badania pozwoliły określić zmiany preferencji przedsiębiorstw w zakresie adaptacyjnego podejścia do zarząazzania projektami oraz wskazały, że w opinii respondentów podstawową korzyścią, jaką osiągają przedsiębiorstwa, wykorzystując podejście adaptacyjne, jest nabywanie umiejętności zarządzania zmieniającymi się priorytetami. Stanowi to odpowiedź na pierwsze pytanie badawcze (PB1). Przedsiębiorstwa, doceniając użyteczność tego podejścia, wykorzystują je na poziomie organizacji, projektu oraz realizującego projekt zespołu. Pośród rozwiązań umożliwiających skalowanie metod zwinnych na poziom organizacji najpowszechniej stosowaną jest Scaled Agile Framework, z uwagi na jej kompleksowość pozwalającą realizować zamierzenia organizacji dzięki zarządzaniu portfelem projektów zwinnych. Analiza zgromadzonych danych wskazuje stały trend rosnący, jeżeli chodzi o respondentów deklarujących stosowanie tej metody (jest to odpowiedź na drugie pytanie badawcze PB2). Na poziomie projektu wykorzystywane są zwinne metodyki zarządzania projektem. Badani najczęściej deklarowali użycie architektury SCRUM. Jej popularność wśród przedsiębiorstw stosujących adaptacyjne podejście do zarządzania projektami jest efektem prostoty tego rozwiązania oraz jego znacznej adaptowalności do potrzeb organizacji. Poszukiwanie metod jak najbardziej dopasowanych do potrzeb przedsiębiorstw jest widoczne w dużej popularności rozwiązań, tj. SCRUM XP Hybrid oraz lączących elementy architektury SCRUM i metody KANBAN (metodyka SCRUMBAN). Wnioski te stanowią odpowiedź na kolejne trzecie pytanie badawcze (PB3). Natomiast, poszukując odpowiedzi na czwarte pytanie badawcze (PB4), analizowano techniki i narzędzia wykorzystywane najczęściej przez zespoły projektowe realizujące projekty zwinne. Najczęściej wykorzystywanymi przez respondentów technikami są planowanie iteracji, codzienne spotkania, przegląd iteracji oraz retrospektywa. Podczas tych wydarzeń najczęściej stosowane są tablice zadań, tablice KANBAN oraz różnego rodzaje arkusze pozwalające zespołowi projektowemu planować i realizować zadania oraz monitorować postęp prac. Jeżeli chodzi o narzędzia informatyczne, to największą popularnością cieszy się wśród respondentów pakiet Atlassian JIRA.

\section{Znaczenie dla praktyki}

Przeprowadzone badania cechują się również wartością dla praktyków. Lektura artykułu może wskazać osobom zainteresowanym wykorzystaniem podejścia adaptacyjnego konkretne rozwiązania, które są obecnie bardzo popularne.

\section{Ograniczenia}

Najważniejszym ograniczeniem prowadzonych analiz jest brak ciągłości prowadzonych przez firmę "Vision One” badań, co przekłada się na sposób publikacji danych oraz ich użyteczność z punktu widzenia postępowania badawczego. 


\section{dr. hab. Mariusz Hofman, prof. uczelni \\ UMCS w Lublinie \\ Wydział Ekonomiczny \\ ORCID: 0000-0002-6866-3906 \\ e-mail: mariusz.hofman@umcs.lublin.pl}

\section{mgr Magdalena Oronowicz \\ UMCS w Lublinie \\ Wydziat Ekonomiczny \\ ORCID: 0000-0001-6595-4049 \\ e-mail: m.oronowicz@poczta.umcs.lublin.pl}

\section{Bibliografia}

[1] Andersen E., Birchall D., Jessen S.A., Money H.A. (2006), Exploring Project Success, „Baltic Journal of Management”, Vol. 1, No. 2, pp. 127-147.

[2] Annual State of Agile Report (lata 2010-2019).

[3] Dybå T., Dingsøyr T. (2008), Empirical Studies of Agile Software Development: A Systematic Review, „Information and Software Technology", Vol. 50, No. 9-10, pp. 833-859.

[4] Friis Sommer A., Dukovska-Popovska I., Steger-Jensen K. (2014), Barriers towards Integrated Product Development - Challenges from a Holistic Project Management Perspective, „International Journal of Project Management”, Vol. 32, No. 6, pp. 970-982.

[5] Dyduch W. (2016), Ilościowe badanie i operacjonalizacja zjawisk w naukach o zarzadzaniu, [w:] W. Czakon (red.), Podstawy metodologii w naukach o zarządzaniu (wydanie III rozszerzone), Wydawnictwo Nieoczywiste, Warszawa, s. 306-328.

[6] Henderson L.S., Stackman R.W., Lindekilde R. (2016), The Centrality of Communication Norm Alignment, Role Clarity, and Trust in Global Project Teams, „International Journal of Project Management", Vol. 34, No. 8, pp. 1717-1730.

[7] Jałocha B. (2019), Projektyzacja jako przedmiot badań $w$ ramach studiów nad projektami, „Przegląd Organizacji”, Nr 8, s. 34-41.

[8] Karrbom Gustavsson T., Hallin A. (2014), Rethinking Dichotomization: A Critical Perspective on the Use of "Hard” and „Soft” in Project Management Research, „International Journal of Project Management", Vol. 32, No. 4, pp. 568-577.

[9] Laanti M., Similä J., Abrahamsson P. (2013), Definitions of Agile Software Development and Agility, [in:] F. McCaffery, R.V. O'Connor, R. Messnarz (eds.), Systems, Software and Services Process Improvement, Vol. 364, Springer, Berlin, Heidelberg, pp. 247-258.

[10] Leffingwell D. (2010), Agile Software Requirements: Lean Requirements Practices for Teams, Programs, and the Enterprise, Addison-Wesley Professional.

[11] Leffingwell D. (2007), Scaling Software Agility: Best Practices for Large Enterprises, Addison-Wesley Professional.

[12] Markowitz H. (1959), Portfolio Selection: Efficient Diversification of Investments, John Wiley and Sons, New York.

[13] Meskendahl S. (2010), The Influence of Business Strategy on Project Portfolio Management and its Success - A Conceptual Framework, „International Journal of Project Management”, Vol. 28, No. 8, pp. 807-817.
[14] Olsson R. (2008), Risk Management in a Multi-project Environment. An Approach to Manage Portfolio Risks, "International Journal of Quality and Reliability Management", Vol. 25, No. 1, pp. 60-71.

[15] Patanakul P., Milosevic D. (2009), The Effectiveness in Managing a Group of Multiple Projects: Factors of Influence and Measurement Criteria, „International Journal of Project Management", Vol. 27, No. 3, pp. 216-233.

[16] Porter W., Lilly S. (1996), The Effects of Conflict, Trust, and Task Commitment on Project Team Performance, „International Journal of Conflict Management”, Vol. 7, No. 4, pp. 361-376.

[17] Project Management Institute (2008), The Standard for Portfolio Management. Global Standard, Newton Square, Pennsylvania.

[18] Schoper Y.-G., Wald A., Ingason H.T. (2018), Projectification in Western Economies: A Comparative Study of Germany, Norway and Iceland, „International Journal of Project Management", Vol. 36, No. 1, pp. 71-82.

[19] Schwaber K., Sutherland J. (2017), The Scrum Guide ${ }^{\text {rxx }}$ The Definitive Guide to Scrum: The Rules of the Game, Scrum.org, Boston, pp. 1-19.

[20] Schwaber K., Beedle M. (2002), Agile Software Development with Scrum. Series in Agile Software Development, Prentice Hall, Upper Saddle River.

[21] Scrum.org (2020), The Scrum Guide ${ }^{\text {tw }}$. The Definitive Guide to Scrum: The Rules of the Game, https:// scrumguides.org/scrum-guide.html, access date: 28.01.2021.

[22] Serrador P., Pinto J. (2015), Does Agile Work? - A Quantitative Analysis of Agile Project Success, „International Journal of Project Management", Vol. 33, No. 5, pp. 1040-1051.

[23] Shu-Chien H., Kai-Wei W., Qingbin C., Rand W. (2016), Understanding the Complexity of Project Team Member Selection through Agent-based Modeling, „International Journal of Project Management", Vol. 34, No. 1, pp. 82-93.

[24] Stettina C., Hörz J. (2015), Agile Portfolio Management: An Empirical Perspective on the Practice in Use, ,International Journal of Project Management", Vol. 33, No. 1, pp. $140-152$.

[25] Sweetman R., Conboy K. (2013), Exploring the Tensions between Software Project Portfolio Management and Agile Methods: A Research in Progress, [in:] B. Fitzgerald, K. Conboy, K. Power, R. Valerdi, L. Morgan, K.-J. Stol (eds.), Proceedings of 4th International Conference, LESS 2013, Springer, Berlin-Heidelberg, pp. 210-217.

[26] Wu G., Liu C., Zhao X., Zuo J. (2017), Investigating the Relationship between Communication-conflict Interaction and Project Success among Construction Project Teams, „International Journal of Project Management”, Vol. 35, No. 8, pp. 1466-1482.

[27] Wyrozębski P. (2020), Zwinne zarządzanie projektami $w$ dużych organizacjach, Oficyna Wydawnicza SGH, Warszawa.

[28] Xiang Ch., Yang Z., Zhang L. (2016), Improving IS Development Teams' Performance During Requirement Analysis in Project - The Perspectives from Shared Mental Model and Emotional Intelligence, „International Journal of Project Management”, Vol. 34, No. 7, pp. 1266-1279. 
Analysis of the Scope and Specificity of Solutions Used as Part of the Adaptive Approach to Project Management

\section{Summary}

The article discusses the issue of the adaptive approach to project management. Its objective is to analyse the application scope of the adaptive approach, including agile management methodologies and the associated tools. The analysis was conducted at the organization, project and team level. The research method used was the analysis of quantitative data. The obtained results enabled to identify the benefits achieved by organisations using the adaptive approach to project management as well as to indicate the most frequent trends in the development of agile scaling methods, agile project management methodologies, and the associated tools and techniques.

\section{Keywords}

adaptive approach, agile methodologies, trend analysis 